Krzysztof Łabędź

ORCID: 0000-0003-2255-3338

Akademia Ignatianum w Krakowie

\title{
Postulaty ustrojowe społeczeństwa polskiego w okresie transformacji systemowej
}

DOI: 10.19195/1643-0328.26.1

Słowa kluczowe: świadomość społeczeństwa polskiego, transformacja systemowa, ustrój polityczny, ustrój społeczno-ekonomiczny

\section{Wprowadzenie}

Okres transformacji systemowej można datować różnie - tutaj przyjęto, że chodzi przede wszystkim o lata 1989-1997, czyli bardzo umownie od wyborów czerwcowych do uchwalenia konstytucji. Należy jednak pamiętać, że transformacja faktycznie zaczęła się wcześniej, a czas jej zakończenia, szczególnie jeśli uwzględnimy przemiany świadomości społecznej, jest trudny do ustalenia. W moim przekonaniu pytaniem pozostaje to, czy obecne przekształcenia polityczne należy traktować jako kolejną fazę transformacji („drugi etap rewolucji”), czy jako odrębny proces.

Transformację można odnosić do trzech zasadniczych sfer: w sferze politycznej jest to zmiana idąca $\mathrm{w}$ kierunku utworzenia systemu demokratycznego, gwarantującego podstawowe prawa i wolności obywatelskie, opartego na pluralizmie politycznym; w sferze ekonomicznej zmiany zmierzały do wprowadzenia gospodarki wolnorynkowej, opartej na własności prywatnej; w sferze świadomościowej (kulturowej) musiało nastąpić dostosowanie sposobów myślenia, postrzegania i oceniania rzeczywistości, nawyków, wzorów zachowań itp. do zmian zachodzących w innych zakresach. Nastąpiło również pełne otwarcie na wpływy zewnętrzne, a wszystko to miało oczywisty wpływ na całość życia społecznego. W adekwatny sposób zmiany te określił Piotr Sztompka, pisząc, że „transformacja postkomunistyczna jest zmianą na najgłębszym, fundamentalnym poziomie życia, z wielkim przełomem kulturowo-cywilizacyjnym"'

${ }^{1}$ P. Sztompka, Teorie zmian społecznych a doświadczenia polskiej transformacji, „Studia Socjologiczne” 1994, nr 1, s. 12. 
Jeśli chodzi o przedmiot postulatów ustrojowych, to można przyjąć, że w zakresie systemu politycznego są to przede wszystkim: kształt demokracji, zakres funkcji państwa, organizacja władz państwowych (ustawodawczych, wykonawczych, sądowniczych) i relacji między nimi, zakres i konstytucyjne gwarancje praw obywatelskich, kierunki polityki zagranicznej, utworzenie i kompetencje samorządu terytorialnego, a także relacje między państwem a Kościołem katolickim. W sferze społeczno-ekonomicznej postulaty tego rodzaju dotyczyły prywatyzacji, urynkowienia gospodarki oraz zasad sprawiedliwego podziału dóbr.

Poniżej zostaną omówione postulaty i poglądy społeczeństwa polskiego dotyczące tych kwestii i wskazujące pożądany kierunek zmian. Ogólnie można stwierdzić, że był on zgodny z kierunkiem reform realizowanych przez polityków, choć nie bez różnych wątpliwości. Oprócz stwierdzenia współwystępowania niektórych poglądów i odpowiadających im działań polityków trudno powiedzieć, czy politycy reagowali na postulaty społeczne, czy też, co bardziej prawdopodobne, kształtowali sposoby myślenia społeczeństwa. Bazę źródłową będą stanowić wyniki badań opinii publicznej, ze świadomością wielu ograniczeń z tym związanych, choć łagodzonych przez powtarzanie badań i prowadzenie ich przez różne ośrodki (CBOS, IFiS PAN, TNS-OBOP). Opinia publiczna jest tutaj rozumiana jako suma odpowiedzi udzielonych w sondażach ankietowych, a charakteryzował ją między innymi John Zaller ${ }^{2}$. Jest ona mniej lub bardziej zróżnicowana $\mathrm{w}$ odniesieniu do wszystkich kwestii, $\mathrm{w}$ wielu przypadkach te same osoby wyrażają (najczęściej nieświadomie) logicznie sprzeczne z sobą poglądy, w znacznej części pozostając pod wpływem bieżących wydarzeń i sytuacji politycznej.

Warto podkreślić, że w części poglądy na temat różnych kwestii zmieniały się, w części straciły na aktualności po wprowadzeniu określonych reform, natomiast w części wykazały pewną trwałość do chwili obecnej, co może wskazywać na względnie stałe predyspozycje do określonego postrzegania i oceniania kwestii związanych z ustrojem ${ }^{3}$. Wśród tych ostatnich można wskazać między innymi ambiwalentne postawy wobec demokracji jako sposobu rządzenia państwem, silną obecność postaw autorytarnych, oczekiwanie realizacji funkcji opiekuńczych przez państwo (znaczny poziom roszczeniowości), uznawanie sprawiedliwości społecznej (rozumianej przede wszystkim jako względna równość) za jedną z najważniejszych wartości, ważniejszą od osiągania dobrobytu, otwarcie na Zachód w polityce zagranicznej, pewną niechęć do polityki i własnego w niej udziału, rozdzielenie państwa i Kościoła, niezadowolenie (i raczej słaba legitymizacja) z istniejącego systemu politycznego niezależnie od okoliczności. Kwestie te w większości znajdą rozwinięcie niżej.

Przedstawianie postulatów i wyobrażeń społeczeństwa polskiego na temat kierunku zmian ustrojowych zachodzących od końca lat osiemdziesiątych (w możliwość zaist-

${ }^{2}$ Charakter opinii publicznej John Zaller określił, pisząc, że mamy do czynienia nie z jedną, a z wieloma wersjami opinii publicznej, ujawniającymi się w zależności od zadawanych pytań i innych czynników sytuacyjnych, zob. idem, J. Zaller, Definicje opinii publicznej, [w:] Władza i społeczeństwo, wybór i oprac. J. Szczupaczyński, Warszawa 1998, s. 221-223.

3 Uprawnia to do stwierdzenia, że w tych przypadkach mamy do czynienia z elementami kultury politycznej. 
nienia których początkowo nie wierzyło wiele osób) warto zacząć od przedstawienia pewnych cech świadomości społeczeństwa, o których należy pamiętać, mówiąc o wysuwanych postulatach.

Po pierwsze, jest to stwierdzenie, że poziom wiedzy politycznej deklarowany przez respondentów w badaniach w zdecydowanej większości nie był i nie jest wysoki (towarzyszy temu łatwość dokonywania ocen). Dominująca część badanych w latach 1984-1990 określała swoje zainteresowanie polityką jako średnie (40-44\%), prawie tyle samo jako nikłe lub żadne, a jako duże lub bardzo duże jedynie 15-22\% (deklaracje bardzo dużego zainteresowania nie przekroczyły w tym czasie $5 \%)^{4}$. Niewielkie zainteresowanie sprawami politycznymi jest jeszcze wyraźniejsze, gdy zadaje się pytanie o znajomość konkretnych kwestii. Jeśli chodzi o znajomość projektu konstytucji, który miał być poddany pod głosowanie w referendum, bardzo dobre poinformowanie o nim zadeklarowało $2 \%$ respondentów, dobre $-5 \%{ }^{5}$, natomiast $11 \%$ stwierdziło, że wiele wie o konkordacie ${ }^{6}$.

Po drugie, warto uświadomić sobie hierarchię problemów dostrzeganych przez społeczeństwo polskie u progu lat dziewięćdziesiątych. Najważniejsze z nich, wymieniane przez 55\% badanych, dotyczyły gospodarki (przede wszystkim poprawa gospodarki $32 \%$, bezrobocia $-24 \%$, rolnictwa $-23 \%$ ), następnie warunków życia $-24 \%$ (przede wszystkim poziomu życia $-35 \%$, wzrostu cen $-20 \%$, niskich płac $-13 \%$ ), a w najmniejszym stopniu polityki $-21 \%$ (przede wszystkim stabilizacji i normalizacji sytuacji politycznej $-52 \%$, jedynie $8 \%$ respondentów wymieniało demokratyzację) $)^{7}$. Daje to dobre wyobrażenie o ważności różnych sfer dla badanych oraz wiedzę, że kwestie kierunków i celów transformacji nie były dla respondentów bardzo istotne. Co oczywiste, interesowały ich te sprawy, które bezpośrednio oddziaływały na ich sytuację życiową.

\section{Poglądy związane z funkcjonowaniem systemu politycznego}

Postulaty dotyczące potrzeby wprowadzenia systemu demokratycznego i określenia jego kształtu miały różną formę, od początku jednak widoczna jest ambiwalencja poglądów w tym zakresie. Początkowo, w latach osiemdziesiątych pytano o to, jaką władzę powinna mieć PZPR. Na podstawie odpowiedzi udzielonych na to pytanie w 1988 roku wyodrębniono trzy niemal równe liczebnie kategorie: zwolenników powiększenia (11\%) lub utrzymania (23,5\%) władzy PZPR - łącznie 34,5\%, zwolenników zmniejszenia władzy PZPR $-33,5 \%$ oraz tych, którzy nie wypowiedzieli się na ten temat $-31,7 \%{ }^{8}$. Można

${ }^{4}$ Czy Polacy interesują się polityką?, komunikat z badań CBOS 256/108/90, https://www.cbos.pl/SPISKOM.POL/1990/K_110_90.PDF (dostęp: 15.10.2018).

5 Wiedza o projektach konstytucji, komunikat z badań CBOS BS/29/29/97, https://www.cbos.pl/SPISKOM.POL/1997/K_029_97.PDF (dostęp: 15.10.2018).

${ }^{6}$ Ratyfikacja konkordatu w opinii społeczeństwa, komunikat z badań CBOS BS/97/95/96, https://www. cbos.pl/SPISKOM.POL/1996/K_098_96.PDF (dostęp: 15.10.2018).

7 Najważniejsze problemy Polski, komunikat z badań CBOS BS/10/33/91, https://www.cbos.pl/SPISKOM.POL/1991/K_010_91.PDF (dostęp: 17.10.2018).

8 W. Adamski et al., Polacy 88. Dynamika konfliktu a szanse reform, Warszawa 1989, s. 281. 
zatem uznać, że około jedna trzecia badanych popierała zmiany idące w kierunku demokracji. Natomiast $\mathrm{w}$ badaniach $\mathrm{z}$ tego samego roku, w których pytano, czym powinno charakteryzować się „dobre społeczeństwo”, 81\% respondentów stwierdziło, że o ustroju państwa powinni decydować wszyscy obywatele, 93\% — że rząd powinien być wybierany przez ludność, a 73,6\% - że ordynacja wyborcza powinna być tak zmieniona, żeby obywatele mogli wybierać między kandydatami o różnych poglądach politycznych ${ }^{9}$. Wynika z tego, że zwolennicy demokratycznych rozwiązań stanowili co najmniej cztery piąte respondentów. W sytuacji, kiedy badania przynoszą tak różne wyniki trzeba sięgnąć do innych wskaźników, na przykład do wyników wyborów z 4 czerwca 1989 roku, w których skomplikowana ordynacja wyborcza uniemożliwia precyzyjne stwierdzenie, na kogo padły oddane głosy, ale analiza dokonana przez Stanisława Gebethnera wskazuje, że w wyborach do Sejmu około 11 mln głosów oddano na "Solidarność, a około $7,6 \mathrm{mln}$ na kandydatów władzy ${ }^{10}$. Trzeba jednak pamiętać, że ponad $37 \%$ elektoratu nie głosowało, czyli nie wypowiedziało się w sprawie kształtu ustroju. Wyniki te można traktować jako dowód, że choć $\mathrm{z}$ jednej strony $\mathrm{w}$ wielu deklaracjach respondenci potwierdzali swoje demokratyczne poglądy, to $\mathrm{z}$ drugiej wiele wskazuje na to, że nie były one i nie są w pełni ugruntowane, a fakt, że jedynie około jedna trzecia ma w pełni demokratyczne przekonania, potwierdza także „Diagnoza społeczna 2015” (tłumacząc to, można sięgnąć do rozróżnienia Stanisława Ossowskiego wartości uznawanych i odczuwanych). Podobne zdanie sformułowali autorzy badań z 1992 roku po stwierdzeniu, że niemal połowa tych, którzy zgadzają się z poglądem o przewadze demokracji nad wszystkimi innymi formami rządów i jednocześnie poglądem, że zdarzają się sytuacje, w których rządy niedemokratyczne mogą być bardziej pożądane niż demokratyczne: „akceptacja obydwu opinii może być elementem jednego, spójnego światopoglądu. Możliwość ich współistnienia wiąże się zapewne ze wskazywaną wcześniej zasadniczą różnicą dzielącą nasz stosunek do zasad i pryncypiów oraz stosunek do polityki rozgrywającej się na naszych oczach. Może być też przejawem rosnącego zagubienia społeczeństwa" ${ }^{11}$.

Także odpowiedzi na pytanie o zasady ustrojowe, wśród których w 1990 roku pytano, czy Polsce potrzebny jest silny przywódca, który zaprowadzi w kraju porządek (twierdząco odpowiedziało 87,8\%), a w 1995 roku, czy nasz kraj potrzebuje nie demokracji, lecz silnego przywódcy (zdanie to potwierdziło 54,5\% badanych), udowadniają wyżej sformułowane zdanie na temat poparcia dla demokracji ${ }^{12}$. Zgadzano się również z następującymi poglądami: „odrobina dyktatury jeszcze nikomu nie zaszkodziła - ktoś powinien silną ręką wziąć się za urzędników i skłócone partie” (71\%) oraz „zamiast partii politycznych ludzie woleliby u władzy zdecydowanego, znającego się na rzeczy człowieka” (69\%) ${ }^{13}$.

Poglądy autorytarne znalazły wyraz także w innych badaniach, na przykład w 1996 roku o tym, że z przestępczością należy walczyć „twardo”, stosując nawet karę śmierci,

9 Wartości i postawy społeczne a zmiany systemowe, red. J. Reykowski, Warszawa 1993, s. 30.

10 S. Gebethner, Wybory do Sejmu i Senatu 1989 r. (wstępne refleksje), „Państwo i Prawo” 1989, nr 8, s. 9.

11 Demokracja i polityka, komunikat z badań CBOS BS/101/82/93, s. 5, https://www.cbos.pl/SPISKOM. POL/1993/K_082_93.PDF (dostęp: 17.10.2018).

12 Polacy'95. Aktorzy i klienci transformacji, red. W. Adamski, Warszawa 1998, s. 224.

13 Demokracja i polityka... 
było przekonanych 70\% badanych (obecnie jest podobnie) ${ }^{14}$, w 1996 roku 75\% respondentów stwierdziło, że prawo nie powinno zezwalać na tworzenie i działanie w Polsce partii lub organizacji homoseksualistów, a $42 \%$ - że nie powinno zezwalać na tworzenie i działanie partii otwarcie krytykującej politykę władz $z^{15}$. W tym samym roku stwierdzono również istnienie wysokiego poziomu dogmatyzmu światopoglądowego (utrzymującego się również dwadzieścia lat później), charakteryzującego myślenie blisko 70\% respondentów, będącego przeciwieństwem pluralizmu i tolerancji, mierzonego między innymi wyrażeniem zgody na stwierdzenia, że „na świecie istnieją dwa typy ludzi: tacy, którzy opowiadają się po stronie prawdy, i tacy, którzy są przeciwko prawdzie”, „nie może przetrwać grupa, która pozwala na to, że jej członkowie mają zbyt wiele różnic w poglądach”, „kompromis zawarty z przeciwnikami politycznymi jest niebezpieczny, ponieważ prowadzi zwykle do zdrady własnych pozycji” ${ }^{16}$.

Ciekawe wydaje się to, jakiej demokracji oczekiwano. W tym zakresie można stwierdzić, że raczej nie liberalnej, raczej dalekiej od wyobrażeń republikańskich (choć występowały oczekiwania dotyczące przeprowadzenia referendów), opartej na rządach prawa, choć nie zawsze przywiązywano duże znaczenie do uchwalenia nowej konstytucji, demokracji realizującej zasady sprawiedliwości społecznej. Odnośnie do naczelnych władz państwa nie było zgodności, a różne poglądy były mniej więcej równo rozłożone.

$\mathrm{W}$ jednym z pierwszych badań przeprowadzonych w trakcie trwającej już transformacji stwierdzono, że demokracja jest $\mathrm{w}$ przekonaniu respondentów stanem pożądanym dla Polski, ale badani nie bardzo wiedzą, na czym ona polega. W efekcie autorzy tych badań skonstatowali, że demokracja funkcjonuje w świadomości Polaków bardziej jako symbol niż konkretna forma oparta na określonych instytucjach i mechanizmach i oznacza pożądany stan organizacji społeczeństwa, w którym ludziom żyje się dobrze. Asumpt do takich stwierdzeń dały między innymi odpowiedzi na pytanie, czy ludziom w Polsce bardziej zależy na uczestnictwie w rządzeniu, czy na tym, żeby nimi dobrze rządzono. Pierwszą z tych możliwości wybrało $22 \%$ badanych, drugą $-62,1 \%$. Jeszcze wyraźniej niechęć do uczestnictwa pokazała się w odpowiedzi na pytanie, czy sam respondent wolałby uczestniczyć w rządzeniu, czy być dobrze rządzonym - jedynie $15,3 \%$ zadeklarowało chęć uczestnictwa, a drugą możliwość wybrało $73,7 \%{ }^{17}$. Podobny rozkład odpowiedzi uzyskano w 1988 oraz w 2001 roku, kiedy to pytanie zadano po raz ostatni ${ }^{18}$. Jako potwierdzenie takiej postawy można uznać równie niewielki (a nawet

14 Kwestie społeczno-polityczne a elektoraty partyjne, komunikat z badań CBOS BS/149/147/96, https:// www.cbos.pl/SPISKOM.POL/1996/K_150_96.PDF (dostęp: 18.10.2018).

15 Prawa i swobody obywatelskie oraz ich granice, komunikat z badań CBOS BS/19/19/96, https://www. cbos.pl/SPISKOM.POL/1996/K_019_96.PDF (dostęp: 18.10.2018).

16 Zob. I. Jakubowska-Branicka, Mentalność demokratyczna a dogmatyzm. Przemiany postaw społeczeństwa polskiego w procesie demokratyzacji, [w:] Wartości, postawy i więzi moralne w zmieniajacym się społeczeństwie, red. J. Mariański, L. Smyczek, Kraków 2008, s. 129.

17 Opinie o zmianach politycznych $i$ demokracji w Polsce, komunikat z badań CBOS BS/120/44/90, https://www.cbos.pl/SPISKOM.POL/1990/K_045_90.PDF (dostęp 20.10.2018).

18 Rozumienie, akceptacja $i$ ocena funkcjonowania polskiej demokracji, komunikat $\mathrm{z}$ badań CBOS BS/114/2001, https://www.cbos.pl/SPISKOM.POL/2001/K_114_01.PDF (dostęp 20.10.2018). 
mniejszy) odsetek osób podejmujących aktywność w organizacjach społecznych, a także utrzymującą się relatywnie niską frekwencję wyborczą, przede wszystkim w wyborach parlamentarnych i samorządowych. Cytowanym wynikom towarzyszyły jednak deklaracje świadczące o chęci uczestnictwa (taka rozbieżność utrzymuje się do chwili obecnej) - ponad połowa respondentów wybrała odpowiedź „chciałbym czynnie uczestniczyć w przemianach, które obecnie zachodzą, ale nie wiem, w jaki sposób mógłbym to zrobić" ${ }^{19}$. Można to uznać za potwierdzenie wniosku, że z jednej strony deklaruje się pewną wartość uznawaną, z drugiej występuje element zagubienia.

Jednocześnie wydaje się, że przynajmniej w warstwie werbalnej pojawiały się aspiracje do uczestnictwa - mogą o tym świadczyć odpowiedzi stwierdzające znaczne poczucie braku wpływu na sprawy kraju (a początkowo również własnego miejsca zamieszkania), deklarowane od lat osiemdziesiątych, niezależnie od zmian ustrojowych, utrzymujące się na poziomie kilkunastu procent respondentów, a także oczekiwania dotyczące przeprowadzania różnych referendów (choć jak wiemy, frekwencja w tych, które zostały przeprowadzone, nie była wysoka). Ponad połowa badanych opowiadała się za przeprowadzeniem referendum w sprawie dopuszczalności aborcji, podobnie w kwestii przeprowadzania prywatyzacji (w obydwu przypadkach $57 \%{ }^{20}$ ), a $78 \%$ chciało w 1994 roku referendum $\mathrm{w}$ sprawie konstytucji ${ }^{21}$.

Wyniki kilku badań można interpretować jako odrzucanie przez większość respondentów demokracji liberalnej, choć inne badania wskazują, że badanym bliskie były idee ograniczenia i kontroli władzy. Wydaje się, że wagę zasady demokracji liberalnej, mówiącej o konieczności silnej gwarancji praw mniejszości, dostrzegało jedynie niewiele więcej niż jedna trzecia społeczeństwa. Mając do wyboru następujące stwierdzenia: „demokracja to przede wszystkim rządzenie państwem zgodnie z wolą większości” oraz „demokracja to przede wszystkim rządzenie państwem tak, by chronione były prawa jednostek", pierwsze z nich wybrało $55,8 \%$ badanych, drugie $-36,7 \%{ }^{22}$. Na pytanie, czy w nowej konstytucji powinny być zagwarantowane przede wszystkim prawa polityczne, takie jak wolność słowa, zrzeszania się, prawo do zgromadzeń, czy też przede wszystkim prawa społeczno-ekononomiczne, takie jak prawo do pracy, godziwej emerytury itp., 24\% opowiedziało się za pierwszą z tych możliwości, a 59\% wybrało drugą ${ }^{23}$. Wcześniej już wspomniano, że znaczna większość opowiedziała się za uniemożliwieniem homoseksualistom tworzenia partii lub innych organizacji.

Natomiast badani wyraźnie opowiadali się za państwem prawa i kontrolą władzy politycznej. Większość była przekonana, że realizacja przez rząd nawet słusznych celów nie

\section{Ibidem.}

20 Referendum - za czy przeciw?, komunikat z badań CBOS BS/430/120/92, https://www.cbos.pl/SPISKOM. POL/1992/K_120_92.PDF. (dostęp: 20.10.2018).

${ }^{21}$ Czy potrzebna jest nowa konstytucja?, komunikat z badań CBOS BS/19/16/94, https://www.cbos.pl/ SPISKOM.POL/1994/K_016_94.PDF (dostęp: 20.10.2018).

22 Stereotypy polityczne i opinie społeczne, komunikat z badań CBOS BS/301/116/90, https://www.cbos. pl/SPISKOM.POL/1990/K_118_90.PDF (dostęp: 14.10.2018).

${ }^{23}$ Kwestie światopoglą̄owe i prawa obywatelskie w konstytucji, komunikat $\mathrm{z}$ badań CBOS BS/54/54/96, https://www.cbos.pl/SPISKOM.POL/1996/K_057_96.PDF (dostęp: 20.10.2018). 
może być usprawiedliwieniem dla łamania konstytucji (tak jest także obecnie) oraz że nie powinno być możliwości szybkiej zmiany konstytucji. Na pytanie zadane w 1993 roku, czy gdyby rząd dla rozwiązania ważnego i pilnego problemu społecznego musiał postąpić niezgodnie z konstytucją, większość respondentów (48\%) uznała, że nie powinien tego robić nawet za cenę nierozwiązania tego problemu, dwa lata później odsetek ten zwiększył się do 54\% (28\% dopuściło taką możliwość, w 1995 roku - 23\%). W 1993 roku większość (54\%) stwierdziła też, że nie powinno być możliwości szybkiej zmiany konstytucji nawet w sytuacji, gdy utrudnia to szybkie rozwiązanie problemów społecznych, dwa lata później było to $57 \%$ (przeciwnego zdania było 25\%, w 1995 roku - 22\%) 2 $^{24}$. Większość (56\%) uznała również, że orzeczenia Trybunału Konstytucyjnego powinny być ostateczne i Sejm nie powinien mieć możliwości ich odrzucenia (przeciwne zdanie miało 23\%). Ponadto respondenci pytani, czym przede wszystkim powinni kierować się posłowie, uchwalając ustawy, na pierwszym miejscu wymienili ich zgodność z konstytucją ${ }^{25}$.

W sprawie oddzielenia państwa i Kościoła deklarowane poglądy były dość jednoznaczne. W 1996 roku o tym, że Kościół powinien być oddzielony od państwa i nie powinien mieszać się do polityki, było przekonanych 79\% (o 9 punktów procentowych więcej niż rok wcześniej) ${ }^{26}$. Natomiast odpowiedzi na pytanie o postulowaną rolę Kościoła w życiu publicznym w Polsce nie były już tak jednoznaczne - 44\% stwierdziło, że powinna być mniejsza, ale $43 \%$ odpowiedziało, że taka jak jest. Część badanych (38\%) stwierdziła, że chcieliby, żeby nowa konstytucja zawierała odwołanie do Boga, niemal tyle samo (36\%) nie chciałoby, dla jednej piątej było to obojętne, 34\% opowiadało się za ratyfikacją konkordatu ( $27 \%$ było przeciwko, przy czym trzeba pamiętać, że ogromna większość nie znała jego treści), 66\% opowiedziało się za nauką religii w szkole, a ponad trzy czwarte uznało, że w nowej konstytucji powinien znaleźć się zapis dotyczący stosunków państwa i Kościoła (być może po to, żeby jasno określić, na czym ma polegać ich rozdzielenie $)^{27}$. Przytoczone wyniki potwierdzają, że z jednej strony neguje się polityczne działania Kościoła, ale z drugiej mniej więcej połowa badanych przyznaje Kościołowi prawo działania w sferze publicznej.

Wybierane przez respondentów rozwiązania $\mathrm{w}$ ramach systemu politycznego w większości były zbliżone do już istniejących, choć w niektórych przypadkach widoczny był pewien sprzeciw wobec koncepcji wzmocnienia prezydentury ówczesnego prezydenta Lecha Wałęsy. W 1994 roku okazało się, że badani są niemal w całości zwolennikami demokracji parlamentarnej - 88\% uznało, że Sejm jest niezbędny, natomiast w przypadku Senatu większość nie przywiązywała wagi do jego istnienia, $41 \%$ uważało, że parlament powinien być jednoizbowy, a tyko $27 \%$ opowiadało się za istnieniem obydwu izb. Jeśli chodzi o relacje pomiędzy różnymi instytucjami władzy, to zdaniem większości respondentów najwyższą władzą powinien być Sejm (42\%), na drugim miejscu znalazł się rząd (lokowany na

${ }^{24}$ Ranga konstytucji w świadomości Polaków, komunikat z badań CBOS BS/43/38/94, https://www. cbos.pl/SPISKOM.POL/1994/K_038_94.PDF (dostęp: 20.10.2018).

${ }_{25}$ Znaczenie prawa i konstytucji, komunikat z badań CBOS BS/39/39/96, https://www.cbos.pl/SPISKOM.POL/1996/K_042_96.PDF (dostęp: 20.10.2018).

${ }^{26}$ Kwestie społeczno-polityczne...

27 Kwestie światopoglądowe... 
drugim miejscu przez $32 \%$, a na pierwszym przez $24 \%$ badanych), na trzecim prezydent (na trzecim miejscu umieszczony przez 37\%, na pierwszym przez 25\%). Ponadto prawie dwie trzecie badanych uznało, że parlament nie powinien być zbyt rozdrobniony i powinni w nim zasiadać przedstawiciele dwóch-trzech partii ${ }^{28}$. Można to uznać za efekt pamięci o kadencji lat 1991-1993 zakończonej rozwiązaniem parlamentu przez prezydenta. Jak okazało się w znacznie późniejszych badaniach, dość trwałe jest wyobrażenie, że najlepszy byłby system dwupartyjny, co jak gdyby łączy dwa przekonania: $\mathrm{z}$ jednej strony istnienie partii politycznych uznawano za potrzebne, $\mathrm{z}$ drugiej nie cieszyły się one sympatią.

Jeśli chodzi o prezydenta, zdecydowana większość uważała, że powinien być wybierany w wyborach powszechnych (89\%), a oprócz tego, żeby nie kierował rządem, ale miał dużo władzy w kraju (48\%), część respondentów uważała przy tym, że zakres władzy prezydenta powinien być taki jak ówcześnie (32\%) i niemal tyle samo, że władza prezydenta była zbyt mała (30\%). Badani stwierdzili, że powinien mieć mniej władzy niż rząd (36\%), choć sporo osób sądziło, że rząd i prezydent powinni mieć mniej więcej tyle samo władzy (31\%). Większość (44\%) była zdania, że o obsadzie wszystkich ministerstw powinien decydować premier, ale duży był także odsetek (34\%) popierających istniejące wtedy rozwiązanie oddające prezydentowi wybór trzech ministrów (spraw zagranicznych, spraw wewnętrznych, obrony narodowej) ${ }^{29}$. Na podstawie tych wyników można sądzić, że około jedna trzecia społeczeństwa byłaby skłonna poprzeć system z silną pozycją prezydenta. Wątek ten był silnie obecny w trakcie prezydentury Wałęsy, a następnie powrócił w okresie prezydentury Lecha Kaczyńskiego.

Już od początku transformacji w społeczeństwie ujawniło się zdecydowane poparcie dla samorządności terytorialnej (było to obecne w żądaniach i programie NSZZ „Solidarność" już w 1981 roku), co oznaczało również decentralizację i ograniczenie władzy centralnej. Reformę samorządową uznawano w 1990 roku za potrzebną — łącznie (bardzo i raczej potrzebna) twierdziło tak $81 \%$ badanych, choć zainteresowanie nią postrzegano jako umiarkowane, a poinformowanie o niej jako niewielkie ${ }^{30}$. Reforma samorządowa spowodowała, że połowa respondentów w 1992 roku deklarowała wzrost wpływu na sprawy związane z miejscem zamieszkania ${ }^{31}$. Również połowa badanych wyrażała aprobatę dla władz swojego miasta czy gminy (pod tym względem władze samorząd we wyraźnie odróżniały się od Sejmu i Senatu) ${ }^{32}$. Uprawnienia władz lokalnych 51\% uznawało za zbyt małe, a kompetencje władz centralnych w stosunku do lokalnych $39 \%$ oceniało jako zbyt duże, co potwierdza poparcie dla samorządności terytorialnej ${ }^{33}$.

28 Społeczna wizja systemu politycznego Polski, komunikat z badań CBOS BS/26/22/94, https://www. cbos.pl/SPISKOM.POL/1994/K_022_94.PDF (dostęp: 21.10.2018).

${ }^{29}$ Ibidem.

30 Społeczne opinie o reformie samorządu terytorialnego, komunikat z badań OBOP nr 8/550/90, http:// tnsglobal.pl/archiv_files/01_503_89.pdf (dostęp: 13.10.2018).

31 Opinie o wplywie społeczeństwa na sytuację w kraju i sprawy życia codziennego, komunikat $\mathrm{z}$ badań CBOS BS/87/9/92, https://www.cbos.pl/SPISKOM.POL/1992/K_009_92.PDF (dostęp: 21.10.2018).

32 Stosunek społeczeństwa do głównych instytucji politycznych i społecznych, komunikat $\mathrm{z}$ badań CBOS BS/378/82/92, https://www.cbos.pl/SPISKOM.POL/1992/K_082_92.PDF (dostęp: 21.10.2018).

33 Społeczna wizja... 
Wypowiadając się na temat głównych kierunków polityki zagranicznej, od początku transformacji badani w zdecydowanej większości nie mieli wątpliwości, że Polska powinna wejść do zjednoczonej Europy. W znacznie mniejszym stopniu dotyczyło to zachodniego sojuszu militarnego. W badaniach prowadzonych na początku 1991 roku $69 \%$ respondentów poparło ideę zjednoczenia całej Europy, choć połowa uznała to za mało prawdopodobne lub wręcz niemożliwe w najbliższych 10-15 latach ${ }^{34}$ (potem odsetek ten uległ pewnemu zmniejszeniu, ale w 1994 roku był dalej znaczący i wynosił 64\%). Jednocześnie 88\% stwierdziło, że Polska powinna ubiegać się o przyjęcie do Europejskiej Wspólnoty Gospodarczej (kojarzonej z wysokim poziomem rozwoju), a 49\% — że po likwidacji Układu Warszawskiego Polska powinna być neutralna (31\% uważało, że powinna związać się sojuszem z Zachodem, później jednak stosunek do przystąpienia Polski do NATO uległ zmianie) $)^{35}$.

Na pytanie, czy badany popierałby przystąpienie Polski do EWG jako pełnoprawny członek, odsetek odpowiedzi pozytywnych zmniejszał się w kolejnych latach (w 1992 roku było to 80\%, w $1993-75 \%$, w $1994-70 \%$ ), ale nadal był bardzo wysoki ${ }^{36}$. Wśród państw, z którymi Polska powinna najściślej współpracować gospodarczo i politycznie, na pierwszych miejscach znalazły się Stany Zjednoczone, Niemcy, Francja, Wielka Brytania i Czechy ${ }^{37}$. Natomiast jeśli chodzi o NATO, to już w 1992 roku odsetek osób twierdzących, że Polska powinna być neutralna, i uważających, że powinna się starać o przyjęcie do NATO, zrównał się (wynosił 35\%), a w kolejnych latach zwolennicy przystąpienia do NATO stanowili już większość (1995 roku było to 65\%) ${ }^{38}$.

\section{Postulaty związane z systemem społeczno-gospodarczym}

Przechodząc do zagadnień związanych z ustrojem społeczno-ekonomicznym, najpierw należy omówić stosunek społeczeństwa do przekształceń własnościowych, przede wszystkim oceny zasadności prywatyzacji. W 1990 roku prywatyzację jako potrzebną w Polsce wymieniło $56,3 \%$ (przeciwnego zdania było $11,5 \%$ ), uzasadniając to między innymi większą dbałością o majątek prywatnych właścicieli, dbałością o jakość i wydajność pracy, uzyskiwanie lepszych wyników produkcyjnych, szansę na uzdrowienie gospodarki. Poparcie prywatyzacji w różnym stopniu dotyczyło rozmaitych instytucji oraz przewidywało różne rozłożenie tego procesu w czasie. Jeśli chodzi o duże przedsiębiorstwa państwo-

34 Opinia publiczna o idei zjednoczenia Europy, komunikat z badań CBOS 66/19/91, https://www.cbos. pl/SPISKOM.POL/1991/K_019_91.PDF (dostęp: 15. 10.2018).

35 Opinia publiczna wobec uczestnictwa Polski w wybranych organizacjach międzynarodowych, komunikat z badań CBOS BS/84/28/91, https://www.cbos.pl/SPISKOM.POL/1991/K_028_91.PDF (dostęp: 15.10.2018).

${ }^{36}$ Opinie o integracji Polski z Uniq Europejska po wejściu w życie układu stowarzyszeniowego, komunikat z badań BS/75/65/94, https://www.cbos.pl/SPISKOM.POL/1994/K_065_94.PDF (dostęp: 15.10.2018).

${ }_{37}$ Miejsce Polski w Europie - pożadani partnerzy gospodarczy $i$ polityczni, komunikat z badań CBOS BS/144/129/94, https://www.cbos.pl/SPISKOM.POL/1994/K_129_94.PDF (dostęp: 15.10.2018).

38 Społeczeństwo polskie wobec NATO - maj '95, komunikat z badań CBOS BS/150/126/95, https:// www.cbos.pl/SPISKOM.POL/1995/K_126_95.PDF (dostęp: 15.10.2018). 
we, to najczęściej stwierdzano, że należy prywatyzować jedynie niektóre z nich (30,3\%), a 17,8\% uznało, że większość. W przypadku handlu i usług przyzwolenie na prywatyzację było większe - prywatyzację większości dopuszczało $27,3 \%$, wszystkich $23 \% 39$.

Podobne wyniki przyniosły badania „Polacy ' 90 ” — za prywatyzacją bez ograniczeń w odniesieniu do wielkich zakładów przemysłowych wypowiedziało się 12,5\% (przeciw prywatyzacji 51,3\%), do banków - 22\% (przeciw 18,9\%), w handlu - 49,4\% (7,3\%), w przypadku szpitali $-10,4 \%(47,6)$, państwowych gospodarstw rolnych $-44,7 \%$ $(12,4 \%)$, w odniesieniu do transportu publicznego $-21,4 \%(28,2 \%)^{40}$. Po upływie roku prywatyzację za korzystną dla gospodarki uznało $42,4 \%$, jako w takim samym stopniu korzystną i niekorzystną $-25,6 \%$, jako niekorzystną — 10,7\% ${ }^{41}$, natomiast w maju 1992 roku te odsetki wyniosły odpowiednio $18 \%, 34 \%, 30 \%$, co oznacza, że w ciągu roku zmieniły się proporcje i zaczęły dominować ambiwalentna i negatywna ocena prywatyzacji $^{42}$. W następnych dwóch latach oceny te poprawiały się i w kwietniu 1994 roku odsetki wynosiły odpowiednio $34 \%, 31 \%$ i $21 \%{ }^{43}$. Oznacza to, że po wystąpieniu różnych negatywnych zjawisk, które wiązano z prywatyzacją, i zawiedzeniu wielu początkowych oczekiwań sytuacja zaczęła się poprawiać i oceny prywatyzacji zaczęły się polepszać. Utrzymywało się zróżnicowanie preferencji odnośnie do prywatyzacji w zależności od działów gospodarki - za prywatyzacją bez ograniczeń w przypadku wielkich zakładów przemysłowych było $10 \%$ (przeciw 32,9\%), banków - 12,4\% (przeciw 32\%), handlu $-46,8 \%$ (9,8\%), szpitali - 10,6\% (48\%), państwowych gospodarstw rolnych - 42,4\% $(17,9 \%)$, transportu publicznego $24,4 \%(29,9 \%)^{44}$.

Począwszy od 1980 roku, w badaniach „Polacy '90” sprawdzano stosunek społeczeństwa do kwestii społeczno-ekonomicznych, składających się na dwa modele: ładu nieegalitarno-rynkowego i egalitarno-etatystycznego. Pierwszy z nich obejmował cztery wskaźniki. Jednym z nich było „zapewnienie silnie zróżnicowanych zarobków zależnie od kwalifikacji” - w 1990 roku odpowiedzi „zdecydowanie tak” i „raczej tak” łącznie udzieliło 78\% badanych, w 1995 roku - 83\%. Następnie pytano o utrzymanie bezrobocia - w tym przypadku zdecydowanie przeważały odpowiedzi negatywne - 64\% w 1990 roku i 82\% pięć lat później, o zwiększenie udziału (w 1990 roku), a w 1995 roku o zwiększenie możliwości sektora prywatnego w gospodarce - twierdząco odpowiedziało $75 \%$ i $69 \%$ badanych. Potrzebę zwiększenia wpływu rządu na gospodarkę, o co pytano jedynie w 1995 roku, dostrzegało 40\%, a odrzucało 51\%. Drugi z tych modeli składał się z następujących twierdzeń: ograniczenie zarobków dla najwyżej zarabiają-

39 Opinie o prywatyzacji gospodarki, komunikat z badań CBOS BS/58/24/90, https://www.cbos.pl/SPISKOM.POL/1995/K_126_95.PDF (dostęp: 12.10.2018).

${ }^{40}$ Polacy'95..., s. 282.

41 Opinia publiczna o sytuacji gospodarczej, polityce ekonomicznej i prywatyzacji, komunikat z badań BS/87/30/91, https://www.cbos.p1/SPISKOM.POL/1991/K_030_91.PDF (dostęp: 12.10.2018).

42 Opinie o prywatyzacji, komunikat z badań CBOS BS/314/36/92, https://www.cbos.p1/SPISKOM. POL/1992/K_036_92.PDF (dostęp: 12.10.2018).

43 Społeczeństwo o prywatyzacji po pierwszym pótroczu rząów lewicy, komunikat z badań CBOS BS/81/71/94, https://www.cbos.pl/SPISKOM.POL/1994/K_071_94.PDF (dostęp: 14.10.2018).

44 Polacy' $95 \ldots$, s. 282. 
cych - w obydwu latach za takim rozwiązaniem była ponad połowa badanych (55\% i 54\%), realizacja polityki pełnego zatrudnienia - za tym opowiedziało się $67 \%$ w 1990 roku i $81 \%$ w 1995, wprowadzenie kontroli państwa nad cenami - za opowiedziało się odpowiednio $66 \%$ i $82 \%$, wprowadzenie centralnego kierowania gospodarką - w tym przypadku przeważały oceny negatywne takiego rozwiązania, odpowiednio $56 \%$ i 57\%, choć warto dodać, że w 1990 roku zwolennicy centralnego kierowania stanowili 31\%. Za samorządnością załóg w zarządzaniu przedsiębiorstwem było odpowiednio 61\% i 77\%, natomiast jeśli chodzi o określenie wysokości płac przez rząd zdania w 1995 roku (wtedy o to spytano) były podzielone - za $44 \%$, przeciw $52 \% 45$.

Przytoczone wyniki badań pozwalają sformułować kilka wniosków. Za autorami badań można stwierdzić, że społeczeństwo opowiadało się za systemem dobrym, łączącym sprawiedliwość i równość z efektywnością gospodarowania, co określono jako myślenie życzeniowe, łączące sprzeczne z sobą rozwiązania. Jest to widoczne szczególnie w odpowiedziach na pytanie o zróżnicowanie zarobków (co najmniej 30\% respondentów udzieliło sprzecznych z sobą odpowiedzi), choć późniejsze badania prowadzą do wniosku, że społeczeństwo nie akceptuje zbyt dużego zróżnicowania, a dopuszczane proporcje pomiędzy najwyższymi i najniższymi zarobkami to jeden do trzech, czterech, maksymalnie jeden do siedmiu. Wyraźnie można dostrzec, że w ciągu pięciu lat, pod wpływem negatywnych skutków transformacji, nasiliły się i tak silne tendencje egalitarne, natomiast $\mathrm{w}$ znacznie mniejszym stopniu poglądy etatystyczne. Jak oszacowali autorzy badań, w 1995 roku za modelem egalitarno-etatystycznym opowiedziało się 30-40\%, za nieegalitarno-rynkowym kilkanaście procent, natomiast około połowy respondentów wybierało rozwiązania wzajemnie sprzeczne, mające złożyć się na „dobry ustrój”.

Charakterystyczne dla społeczeństwa polskiego jest traktowanie sprawiedliwości społecznej, rozumianej przede wszystkim jako zmniejszanie zróżnicowania społecznego, jako jednej z dwóch, oprócz wolności, naczelnych wartości politycznych (szczególnie wśród osób mniej wykształconych i o niższych dochodach). W 1991 roku stwierdzenie, że „biedne społeczeństwa powinny szczególnie pilnować, by to, co posiadają, było sprawiedliwie dzielone między wszystkich" zostało wybrane przez 57,5\% badanych; alternatywą było stwierdzenie, że „biedne społeczeństwa powinny przede wszystkim ciężko pracować”, wybrane przez $37 \%{ }^{46}$. Wynik taki można zinterpretować jako koncentrację nie na zwiększeniu tego, co będzie przedmiotem podziału, ale przede wszystkim na samym podziale - w odniesieniu do początku lat osiemdziesiątych sytuację taką opisywała Jadwiga Staniszkis. W 1995 roku 37\% respondentów za najważniejszą wartość uznało wolność, a 33\% sprawiedliwość społeczną. Co ciekawe, zarówno wtedy, jak i poprzednio oraz obecnie sprawiedliwość była zdecydowanie ważniejsza niż dobrobyt $(16 \%)$ czy równość wobec prawa $(14 \%)^{47}$.

Charakterystyczny jest także sposób postrzegania funkcji państwa, które w opinii zdecydowanej większości powinno mieć $\mathrm{w}$ dalszym ciągu charakter opiekuńczy, zagwarantować

45 Ibidem, s. 127-128. Zob. też Preferencje społeczno-gospodarcze Polaków, komunikat z badań CBOS BS/276/29/92, https:/www.cbos.pl/SPISKOM.POL/1992/K_029_92.PDF (dostęp: 14.10.2018).

46 Stereotypy...

47 Społeczna wizja ustroju demokratycznego, komunikat z badań CBOS BS/118/99/95, https://www. cbos.pl/SPISKOM.POL/1995/K_099_95.PDF (dostęp: 14.10.2018). 
nieodpłatne świadczenia socjalne lub do nich dopłacać. W 1992 roku respondenci wśród najważniejszych celów działania państwa na pierwszym miejscu wymienili zapewnienie lepszej ochrony zdrowia i oświaty $-94 \%$, zmniejszenie bezrobocia $-90 \%$, dobranie znających się na rzeczy fachowców do kierowania gospodarką - 89\%, zapewnienie ładu i bezpieczeństwa publicznego $-87 \%$, zwiększenie emerytur i zasiłków socjalnych $-86 \%$, skuteczniejszą ochronę środowiska - 86\%, zmniejszenie niesprawiedliwych nierówności między ludźmi $-84 \%{ }^{48}$. Widać $\mathrm{z}$ tego, że wśród oczekiwań wobec państwa dominowały (i nadal dominują) oczekiwania związane ze sferą socjalną, a w związku z ograniczeniem państwa opiekuńczego badani twierdzili, że państwo nie wywiązuje się ze swoich funkcji związanych z szeroko pojętą ochroną obywateli. Na dalszych pozycjach wymieniono również zapewnienie dobrobytu, natomiast wprowadzenie gospodarki rynkowej czy prywatyzacja przedsiębiorstw państwowych nie były dla badanych bardzo ważnymi celami.

\section{Zakończenie}

Na podstawie przytoczonych wyników badań można wysunąć kilka wniosków. Jeden z nich dotyczy wspomnianej już różnicy między wartościami uznawanymi, obecnymi głównie w sferze deklaracji, oraz odczuwanymi, których wskaźnikami mogą być zachowania. Można sądzić, że społeczeństwo było częściowo zagubione w nowej rzeczywistości, a jego postulaty odnoszące się do tej rzeczywistości często wyrażały dążenie do jakiegoś niemożliwego systemu, który godziłby sprzeczne z sobą oczekiwania. Trzeba przy tym pamiętać o wspomnianych uwarunkowaniach, wpływających na sposób postrzegania i rozumienia zjawisk i procesów politycznych (zainteresowane i wiedza polityczna) oraz ich ewaluacji (podstawowym kryterium są własne interesy).

W efekcie utrzymywała się, także w okresie późniejszym, przewaga ocen negatywnych istniejącego systemu politycznego, niezależnie od zasadniczej zmiany zarówno tego systemu, jak i warunków w jego otoczeniu. Zarówno w styczniu 1989 roku, jak i w październiku 1995 (a także później) najczęstsze były stwierdzenia, że nasz system polityczny nie jest zbyt dobry i wymaga wielu zmian (odpowiednio $49 \%$ i $42 \%$ ). Ponadto odpowiedź „nasz system polityczny jest zły i wymaga zasadniczych zmian” wybrało w 1989 roku 22\% badanych, w 1995 roku - 17\%, co oznacza, że w obydwu przypadkach przeważały oceny negatywne $(71 \% \text { i 59\% })^{49}$. Co ciekawe, w kwietniu 1993 roku $39 \%$ respondentów stwierdziło, że istniejący system jest bliżej niedemokratycznego niż demokratycznego, a w maju 1995 roku odsetek ten wzrósł do $51 \%{ }^{50}$. Można to (wraz z późniejszymi wynikami) określić jako stan permanentnego niedosytu legitymizacji.

48 Cele ważne dla społeczeństwa, komunikat $\mathrm{z}$ badań CBOS BS/399/97/92, https://www.cbos.pl/SPISKOM.POL/1992/K_097_92.PDF (dostęp: 15.10.2018).

49 Polacy o demokracji, komunikat z badań CBS BS/141/2003, https://www.cbos.pl/SPISKOM.POL/2003/K_141_03.PDF (dostęp: 15.10.2018).

50 Społeczna wizja ustroju... 


\section{Bibliografia}

Adamski W., Jasiewicz K., Kolarska-Bobińska L., Rychard A., Wnuk-Lipiński E., Polacy 88. Dynamika konfliktu a szanse reform, IFiS PAN, Warszawa 1989.

Cele ważne dla społeczeństwa, komunikat z badań CBOS BS/399/97/92, https://www.cbos.pl/SPISKOM. POL/1992/K_097_92.PDF (dostęp: 15.10.2018).

Czy Polacy interesują się polityką?, komunikat z badań CBOS 256/108/90, https://www.cbos.pl/SPISKOM. POL/1990/K_110_90.PDF (dostęp: 15.10.2018).

Czy potrzebna jest nowa konstytucja?, komunikat z badań CBOS BS/19/16/94, https://www.cbos.pl/SPISKOM.POL/1994/K_016_94.PDF (dostęp: 20.10.2018).

Demokracja i polityka, komunikat z badań CBOS BS/101/82/93, https://www.cbos.pl/SPISKOM.POL/1993/K_082_93.PDF (dostęp: 17.10.2018).

Gebethner S., Wybory do Sejmu i Senatu 1989 r. (wstępne refleksje), „Państwo i Prawo” 1989, nr 8.

Jakubowska-Branicka I., Mentalność demokratyczna a dogmatyzm. Przemiany postaw społeczeństwa polskiego w procesie demokratyzacji, [w:] Wartości, postawy i więzi moralne w zmieniającym się społeczeństwie, red. J. Mariański, L. Smyczek, WAM, Kraków 2008.

Kwestie społeczno-polityczne a elektoraty partyjne, komunikat z badań CBOS BS/149/147/96, https://www. cbos.pl/SPISKOM.POL/1996/K_150_96.PDF (dostęp: 18.10.2018).

Kwestie światopoglądowe i prawa obywatelskie w konstytucji, komunikat z badań CBOS BS/54/54/96, https:// www.cbos.pl/SPISKOM.POL/1996/K_057_96.PDF (dostęp: 20.10.2018).

Miejsce Polski w Europie — pożądani partnerzy gospodarczy i polityczni, komunikat z badań CBOS BS/144/129/94, https://www.cbos.pl/SPISKOM.POL/1994/K_129_94.PDF (dostęp: 15.10.2018).

Najważniejsze problemy Polski, komunikat z badań CBOS BS/10/33/91, https://www.cbos.pl/SPISKOM. POL/1991/K_010_91.PDF (dostęp: 17.10.2018).

Opinia publiczna o idei zjednoczenia Europy, komunikat z badań CBOS 66/19/91, https://www.cbos.pl/SPISKOM.POL/1991/K_019_91.PDF (dostęp: 15.10.2018).

Opinia publiczna o sytuacji gospodarczej, polityce ekonomicznej i prywatyzacji, komunikat z badań CBOS BS/87/30/91, https://www.cbos.pl/SPISKOM.POL/1991/K_030_91.PDF (dostęp: 12.10.2018).

Opinia publiczna wobec uczestnictwa Polski w wybranych organizacjach międzynarodowych, komunikat z badań BS/84/28/91, https://www.cbos.pl/SPISKOM.POL/1991/K_028_91.PDF (dostęp: 15.10.2018).

Opinie o prywatyzacji, komunikat z badań CBOS BS/314/36/92, https://www.cbos.pl/SPISKOM.POL/1992/K_036_92.PDF (dostęp: 12.10.2018).

Opinie o prywatyzacji gospodarki, komunikat z badań CBOS BS/58/24/90, https://www.cbos.pl/SPISKOM.POL/1995/K_126_95.PDF (dostęp: 12.10.2018).

Opinie o wplywie społeczeństwa na sytuację w kraju i sprawy życia codziennego, komunikat $\mathrm{z}$ badań CBOS BS/87/9/92, https://www.cbos.pl/SPISKOM.POL/1992/K_009_92.PDF (dostęp: 21.10.2018).

Opinie o zmianach politycznych i demokracji w Polsce. https://www.cbos.pl/SPISKOM.POL/1990/K_045_90. PDF (dostęp: 20.10.2018).

Polacy '95. Aktorzy i klienci transformacji, red. W. Adamski, IFiS PAN, Warszawa 1998.

Polacy o demokracji, komunikat z badań CBOS BS/141/2003, https://www.cbos.pl/SPISKOM.POL/2003/K_141_03. PDF (dostęp: 15.10.2018).

Prawa i swobody obywatelskie oraz ich granice, komunikat z badań CBOS BS/19/19/96, https://www.cbos.pl/ SPISKOM.POL/1996/K_019_96.PDF (dostęp: 18.10.2018).

Preferencje społeczno-gospodarcze Polaków, komunikat z badań CBOS BS/276/29/92, https://www.cbos.pl/ SPISKOM.POL/1992/K_029_92.PDF (dostęp: 14.10.2018).

Ranga konstytucji w świadomości Polaków, komunikat z badań CBOS BS/43/38/94, https://www.cbos.pl/ SPISKOM.POL/1994/K_038_94.PDF (dostęp: 20.10.2018).

Ratyfikacja konkordatu w opinii społeczeństwa, komunikat z badań CBOS BS/97/95/96, https://www.cbos. pl/SPISKOM.POL/1996/K_098_96.PDF (dostęp: 15.10.2018). 
Referendum - za czy przeciw?, komunikat z badań CBOS BS/430/120/92 https://www.cbos.pl/SPISKOM.POL/1992/K_120_92.PDF (dostęp: 20.10.2018).

Rozumienie, akceptacja i ocena funkcjonowania polskiej demokracji, komunikat z badań CBOS BS/114/2001, https://www.cbos.pl/SPISKOM.POL/2001/K_114_01.PDF (dostęp: 20.10.2018).

Społeczeństwo o prywatyzacji po pierwszym pótroczu rządów lewicy, komunikat z badań CBOS BS/81/71/94, https://www.cbos.pl/SPISKOM.POL/1994/K_071_94.PDF (dostęp: 14.10.2018).

Społeczeństwo polskie wobec NATO - maj '95, komunikat z badań CBOS BS/150/126/95, https://www.cbos. pl/SPISKOM.POL/1995/K_126_95.PDF (dostęp: 15.10.2018).

Społeczna wizja systemu politycznego Polski, komunikat z badań CBOS BS/26/22/94, https://www.cbos.pl/ SPISKOM.POL/1994/K_022_94.PDF (dostęp: 21.10.2018).

Społeczna wizja ustroju demokratycznego, komunikat z badań CBOS BS/118/99/95, https://www.cbos.pl/ SPISKOM.POL/1995/K_099_95.PDF (dostęp: 14.10.2018).

Społeczne opinie o reformie samorzadu terytorialnego, komunikat z badań OBOP nr 8/550/90, http://tnsglobal.pl/archiv_files/01_503_89.pdf (dostęp: 13.10.2018).

Stereotypy polityczne i opinie społeczne, komunikat z badań CBOS BS/301/116/90, https://www.cbos.pl/SPISKOM.POL/1990/K_118_90.PDF (dostęp: 14.10.2018).

Stosunek społeczeństwa do głównych instytucji politycznych i społecznych, komunikat z badań CBOS BS/378/82/92, https://www.cbos.pl/SPISKOM.POL/1992/K_082_92.PDF (dostęp: 21.10.2018).

Sztompka P., Teorie zmian społecznych a doświadczenia polskiej transformacji, „Studia Socjologiczne” 1994, $\mathrm{nr} 1$.

Wartości i postawy społeczne a zmiany systemowe, red. J. Reykowski, Instytut Psychologii PAN, Warszawa 1993.

Wiedza o projektach konstytucji, komunikat z badań CBOS BS/29/29/97, https://www.cbos.pl/SPISKOM. POL/1997/K_029_97.PDF (dostęp: 15.10.2018).

Zaller J., Definicje opinii publicznej, [w:] Władza i społeczeństwo, wybór i oprac. J. Szczupaczyński, Scholar, Warszawa 1998.

Znaczenie prawa i konstytucji, komunikat z badań CBOS BS/39/39/96, https://www.cbos.pl/SPISKOM.POL/1996/K_042_96.PDF (dostęp: 20.10.2018).

\title{
Polish society's demands on the political system in the period of systemic transformation
}

Keywords: Polish society's awareness, systemic transformation, political system, social and economic system

\begin{abstract}
Summary
It has been widely accepted that the demands which accompanied the systemic transformation, with regard to the political system, concerned above all the shape of democracy, the scope of the state's functions, organisation of the state authorities and the relations between them, the scope and the constitutional guarantees of the civic rights, the foreign policy priorities, establishment of the territorial self-government as well as the relations between the state and the Catholic Church. In the economic sphere, the demands concerned primarily privatisation, implementation of market economy and the principles of equitable distribution of wealth. The paper discusses views within the Polish society concerning these issues and indicating the desirable development trends. In general, it can be stated that these trends were consistent with the trends of the reforms implemented by politicians, albeit not without some differences and doubts.
\end{abstract}

